\title{
Thallium-doped sulphate potassium crystals as materials for radiation detectors
}

\author{
M.Myrzakhmet, M.Nikl*, V.Jary", B.Dalelkhan, A.Zhanabergenov \\ Eurasian National University, \\ 5 Munaytpasov St., 010008 Astana, Kazakhstan \\ "Institute of Physics, Academy of Sciences of Czech Republic, \\ 10 Cukrovarnicka, 16253 Prague, Czech Republic
}

Received April 2, 2013

\begin{abstract}
Luminescence characteristics of potassium sulphate $\left(\mathrm{K}_{2} \mathrm{SO}_{4}\right)$ crystals doped with thallium were studied. Crystals were grown from water solution at slightly elevated temperature. The nature and properties of the luminescence centres in these crystals have been determined. The main monovalent thallium luminescence centres show the absorption peak at $216 \mathrm{~nm}$ and emission one peaking at $285 \mathrm{~nm}$ at room temperature. Thallium is substituting potassium which has two different positions in $\mathrm{K}_{2} \mathrm{SO}_{4}$ structure. Consequently, two different $\mathrm{Tl}^{+}$centers were found for thallium centers in these crystals and the third center includes an unspecified perturbation agent nearby. $\mathrm{TI}^{+}$centers differ in radiative lifetime at low temperatures and in temperature dependence of decay times measured within $8-300 \mathrm{~K}$.
\end{abstract}

Исследованы люминесцентные характеристики кристаллов сульфат калия $\left(\mathrm{K}_{2} \mathrm{SO}_{4}\right)$, активированных таллием. Кристаллы выращены из водного раствора при комнатной температуре. Определены природа и свойства центров люминесценции в этих кристаллах. Основной одновалентный таллиевый центр люминесценции имеет при комнатной температуре поглощение при 216 нм и излучение при 285 нм. Таллий замещает калий, который имеет две различные позиции в структуре $\mathrm{K}_{2} \mathrm{SO}_{4}$. Определены два различных $\mathrm{Tl}^{+}$-центра для таллиевых центров в этих кристаллах, а также третий центр, который включает в себя пока неизвестный агент возмущения поблизости. $\mathrm{Tl}^{+}$-центры отличаются радиационным временем жизни при низких температурах и по температурной зависимости времени затухания, измеренных в диапазоне 8-300 К.

Особливості кристалів сульфату калію як матеріалів для детекторів випромінювань. М.Мирзахмет, М.Нікл, В.Джері, Б.Далельхан, А.Жанабергенов.

Досліджено люмінесцентні характеристики кристалів сульфату калію $\left(\mathrm{K}_{2} \mathrm{SO}_{4}\right)$, активованих талієм. Кристали вирощено з водного розчину при кімнатній температурі. Визначено природу і властивості центрів люмінесценції в цих кристалах. Основний одновалентний талієвий центр люмінесценції має при кімнатній температурі поглинання при 216 нм і випромінювання при 285 нм. Талій заміщає калій, який має дві різні позиції у структурі $\mathrm{K}_{2} \mathrm{SO}_{4}$. Визначено два різних $\mathrm{Tl}^{+}$-центра для талієвих центрів в цих кристалах, а також третій центр, який включає поки невідомий агент обурення поблизу. $\mathrm{Tl}^{+}$-центри відрізняються радіаційним часом життя при низьких температурах і по температурній залежності часу загасання, виміряних у діапазоні 8-300 К.

\section{Introduction}

One of the most widely used recent methods of synthesis of nanostructures are the so-called method of "soft chemistry" that allows to create a wide range of nanomaterials in solutions using controlled phase formation and crystallization processes (colloi- 
dal synthesis, sol-gel method, synthesis in microemulsions) target self-assembly of nano-objects into ordered 2D and 3D assemblies (template synthesis aimed sedimentation, convection self-assembly) [1].

Such systems become demanding in the information processing. The development of technologies is required for manufacturing to broadcasting/excitation devices, photodetectors and light-controlled logic gates.

On the other hand, such nanomorphological systems can arise by self-organization, which is the case of naturally occurring material with properties of photonic crystal precious opal. As a result of long-term research and experiments, carried out in various laboratories of the world, various methods for artificial synthesis of this mineral have been developed.

The technology of producing opal matrixes with regular packs is developed highly most fully for silicon dioxide $\left(\mathrm{SiO}_{2}\right)$. On this basis the three-dimensional characteristic nanocomposites with nanoscale structure are obtained. These structures provide a photonic material properties and formed a whole branch of research in the field of opal photonic crystals [2].

Nanocomposites using the precious opal host were created by filling its regular nanocavities by precious metals, nanocrystals of semiconductors and nanocrystals of crystalline phosphors on the basis of rareearth ions [1]. So far the ionic nanocrystals with tetrahedrally-coordinated anions or cations have not been used for such a purpose. Tl-doped $\mathrm{K}_{2} \mathrm{SO}_{4}$ could be suitable for such a purpose, but before the manufacturing and study of such nanocomposites we report here the detailed study of $\mathrm{Tl}^{+}$emission center characteristics in potassium sulphate crystal host to have the material description in its bulk form. The $\mathrm{Tl}^{+}$luminescence centers in these crystals were briefly described in [19].

Potassium sulphate $\left(\mathrm{K}_{2} \mathrm{SO}_{4}\right)$ at room temperature refers to the orthorhombic space group $D_{2 h}{ }^{16}=$ Pnma $[3,4]$, and at $587^{\circ} \mathrm{C}$ undergoes a phase transition to the hexagonal structure $D_{6 h}{ }^{4}=P 63 / m m c$ [5]. The hexagonal high-temperature phase of the crystal is usually referred to as $\alpha-\mathrm{K}_{2} \mathrm{SO}_{4}$, and the orthorhombic phase - as $\beta-\mathrm{K}_{2} \mathrm{SO}_{4}$. Similar phase transitions from $\alpha$-type structure to $\beta$-type structure werefound for other crystals of the family (e.g., $\mathrm{Na}_{2} \mathrm{SO}_{4}$, $\mathrm{LiKSO}_{4}, \mathrm{~K}_{2} \mathrm{CrO}_{4}$ and $\mathrm{K}_{2} \mathrm{SeO}_{4}$ ) [6, 7]).

Another phase transition at $56 \mathrm{~K}$ is found by the authors [8]. The crystal symmetry of the low-temperature phase $\left(\gamma-\mathrm{K}_{2} \mathrm{SO}_{4}\right)$ is monoclinic. However, the authors of [9] did not find any evidence in favor of a phase transition below room temperature.

In [10] it is shown that the phase transition between the $\beta-\mathrm{K}_{2} \mathrm{SO}_{4}$ and $\alpha-\mathrm{K}_{2} \mathrm{SO}_{4}$ is a phase transition of the first kind. Pretransition effects lower than the temperature of phase transition are attributed to the water that is usually within the crystals grown from aqueous solutions. The authors [10] believe that the previous reports on such effects [11-13] should be treated with caution, because it is not clear whether these effects are related to the mobility of $\mathrm{K}^{+}$or $\mathrm{SO}_{2}{ }^{-4}$, or the mobility of extrinsic species like $\mathrm{OH}_{3}{ }^{+}$.

Undoped single crystals of potassium sulphate are transparent in a wide spectral range up to $8.0 \mathrm{eV} \mathrm{[14]} \mathrm{and} \mathrm{show} \mathrm{no} \mathrm{absorp-}$ tion or fluorescence in the broad spectral range of 200-800 $\mathrm{nm}$ before and after $\mathrm{X}$-ray irradiation of the samples [17].

Absorption spectra of thallium-activated $\mathrm{K}_{2} \mathrm{SO}_{4}$ crystals show bands with maxima at 5.7 and $7.3 \mathrm{eV}$, associated with transitions of the $\mathrm{Tl}^{+}$-ion with a maximum of emission near $4.2 \mathrm{eV}$ [15]. With an increase in concentration of thallium the additional $\mathbf{5 . 6 5}$ and $4.4 \mathrm{eV}$ absorption bands arise the intensity of which changes linearly with the concentration of the impurity; the maximum of related emission band is at $3.5 \mathrm{eV}$. It is expected that the absorption bands of 5.75 and $7.35 \mathrm{eV}$ and $4.2 \mathrm{eV}$ emission band correspond to transitions in $\mathrm{Tl}^{+}$-ions in $k 1$ positions, while the absorption bands at 4.4 and $5.65 \mathrm{eV}$ and $3.5 \mathrm{eV}$ emission band correspond to transitions of $\mathrm{Tl}^{+}$-ions in the $k 2$ position.

When heating the irradiated crystals the intensive thermoluminescence in the 90$200 \mathrm{~K}$ range in the $2.35 \mathrm{eV}$ emission band is observed. At high temperatures thermoluminescence spectra show bands with maxima at 4.2 and $3.5 \mathrm{eV}$ coinciding with the intracenter luminescence of $\mathrm{Tl}^{+}$-ions in $k 1$ and $k 2$ positions.

As it is shown in [16] by EPR method, $\mathrm{X}$-ray radiation effectively creates the $\mathrm{T}^{2+}$ centers. Authors [14] connect the luminescence of $\mathrm{Tl}^{+}$-centers in thermoluminescence spectra with a recombination of $\mathrm{Tl}^{2+}$-centers with electrons.

The potassium sulphate activated by thallium shows an absorption band in ultraviolet area with a maximum at $5.85 \mathrm{eV}$. After X-ray irradiation of crystals the intensity of this band decreases slightly, and the weak shoulder shows up in 5.5-5.6 eV region [17]. The emission spectra consist of 


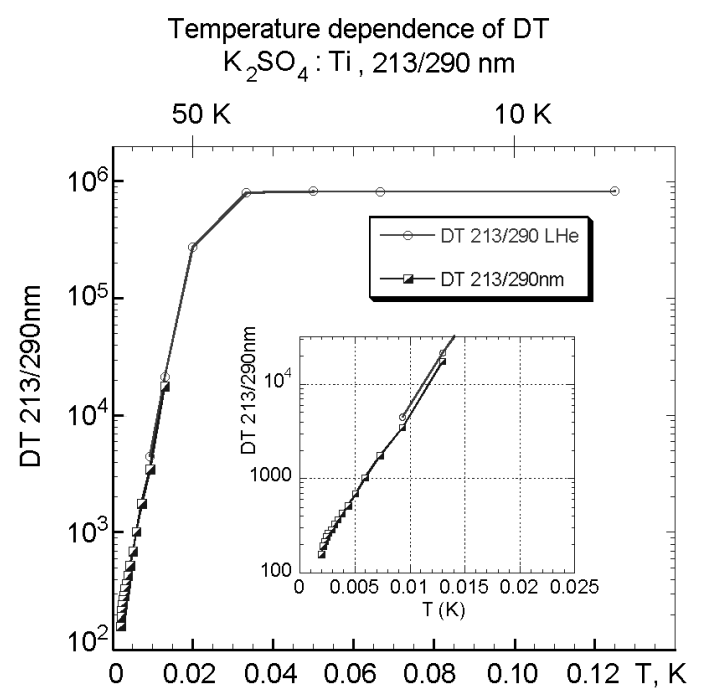

Fig. 1. The temperature dependence of the decay time of the emission band at $285 \mathrm{~nm}$ (at excitation in $213 \mathrm{~nm}$, and the emission at $290 \mathrm{~nm}$ ), obtained from a single-exponential approximation of decay curves. The inset shows enlarged the $70-500 \mathrm{~K}$ region.

two bands: intensive $4.0 \mathrm{eV}$ band and a weak band around 2.02-2.05 eV. The excitation spectra corresponding to these emission bands are similar. They have maximum at $5.4 \mathrm{eV}$ and a shoulder at higher energy within 5.8-5.9 eV. Gamma irradiation of crystals does not give rise to any new excitation/emission bands.

For low irradiation doses the thermally stimulated luminescence shows three glow curve peaks with maxima at 340,395 and $445 \mathrm{~K}$. The low-temperature peak with an increase in a dose of radiation is overlapped by the second peak. There is a considerable afterglow after the usual doses of radiation. Spectral structures of afterglow, as well as thermoluminescence under various peaks, consist of two bands $2.04 \mathrm{eV}$ and $4.0 \mathrm{eV}$. The low-energy band is quite weak at the room temperature and lower temperatures, but its intensity increases significantly at higher temperatures [17].

In the optical absorption spectra the $C$ absorption band of $\mathrm{Tl}^{+}$-ions is shown. The fluorescence shows emission of $\mathrm{Tl}^{+}$due to transitions from the ${ }^{3} P_{1}$ and ${ }^{3} P_{0}$ levels on ${ }^{1} S_{0}$ level. Gamma irradiation causes a change in the valence of some of the $\mathrm{Tl}^{+}$-ions. $\mathrm{Tl}^{+}$behaves during irradiation as an electronic trap. Formed $\mathrm{Tl}^{0}$, evolving into $\mathrm{Tl}^{+}$at the time of recombination with the hole in the center of the heating time, and this causes the observed rec ombination thermoluminescence. The emission spectra of thermolumi-



Fig. 2. The temperature dependence of the decay time of the $330 \mathrm{~nm}$ band, obtained from a single-exponential approximation of the decay curves.

nescence contain the same band of $\mathrm{Tl}^{+}$, as observed in the fluorescence [17].

In [18] it is shown that radiation X-ray beams of crystals at a temperature of liquid nitrogen leads to the formation of the $\mathrm{Tl}^{0}$ and $\mathrm{Tl}^{2+}$ centers. When heating crystals to room temperature the intensive thermoluminescence is observed associated with the decay of these centers.

For crystals of potassium sulphate, activated by thallium, a number of questions was not solved:

- uncertainty of a shape and position $A$-, $B$-, $C$-bands absorption of $\mathrm{Tl}^{+}$-ions,

- difference in the optical properties of $\mathrm{Tl}^{+}$-ions for two various positions of potassium which they replace,

- optical properties of $\mathrm{Tl}^{+}{ }_{2}$ pair centers in these crystals.

\section{Experimental}

Pure and thallium doped potassium sulphate crystals are grown in our laboratory from water solution by a method of slow evaporation at the room temperature. Measuring the optical properties of these crystals are carried out on the equipment of the Department of Optical Materials Institute of Physics of the Academy of Sciences of the Czech Republic in Prague [19]. Absorption of crystals was measured at the room temperature on the Shimadzu 3101PC spectrometer, luminescence spectra and decay kinetics were measured on HJY 5000M spectrofluorometer within 77-500 K. 
$\mathrm{K}_{2} \mathrm{SO}_{4}-\mathrm{TiCi}-2004$ excitation spectra at $77 \mathrm{~K}$

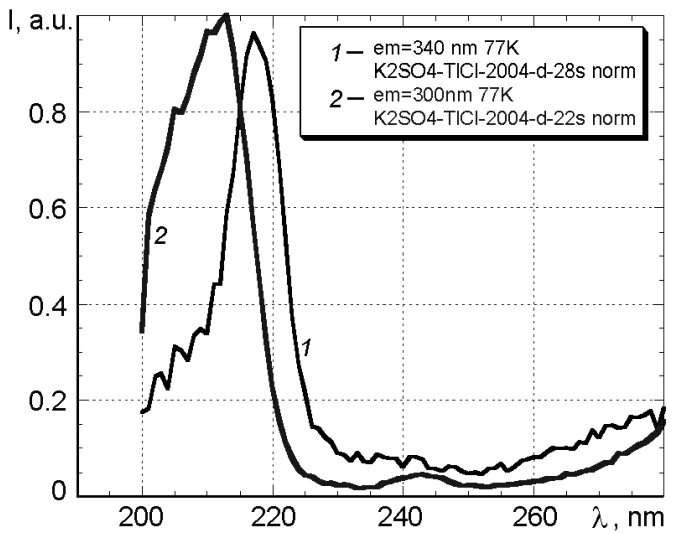

Fig. 3. Photoluminescence excitation spectra at $77 \mathrm{~K}$, excited at $340 \mathrm{~nm}$ and $300 \mathrm{~nm}$.

\section{Results and discussion}

In X-ray excited luminescence spectra the samples doped by thallium always showed a more intensive band of emission with various intensity (depending on a shape of a sample, the concentration of thallium, the quality of a material).

The absorption spectra of the samples with impurity of thallium $A$-band of $\mathrm{Tl}^{+}$-ions with a maximum about $216 \mathrm{~nm}$. Some of the undoped samples showed contamination by thallium and the same emission band, as in the $\mathrm{Tl}$-doped samples.

Upon excitation in the $A$-band near $216 \mathrm{~nm}$ the emission band is observed with a maximum at $285 \mathrm{~nm}$, which belongs to the $\mathrm{Tl}^{+}$.

The excitation spectrum of the $285 \mathrm{~nm}$ band approximately copies the absorption $A$-band, some distortions arise likely due to high absorbance and resulting geometrical effects.

Thus, the luminescence centers in the crystals of potassium sulphate doped by thallium show absorption with a maximum at $216 \mathrm{~nm}$ and emission with a maximum at $285 \mathrm{~nm}$ at the room temperature. These centers belong to monovalent of thallium. Two different substitution sites show small effect in the luminescent characteristics.

Decay kinetic measurements complete further the descirption of the $\mathrm{Tl}^{+}$centers (Fig. 1). Measurement of KSO:TI down to $8 \mathrm{~K}$ showed a plateau in the decay time of a dominating band at $285 \mathrm{~nm}$ (lower than $30 \mathrm{~K})$, but for the decay time of a band at $330 \mathrm{~nm}$ we have growth up to $8 \mathrm{~K}$, so in this case division of metastable and radiating levels of this center less authentically, then at a $285 \mathrm{~nm}$ band.
$\mathrm{K}_{2} \mathrm{SO}_{4}-\mathrm{TiCi}-2004-\mathrm{D}$

Emission spectrum, ex $=243 \mathrm{~nm} \quad T=77 \mathrm{~K}$; Slits $8 / 6$

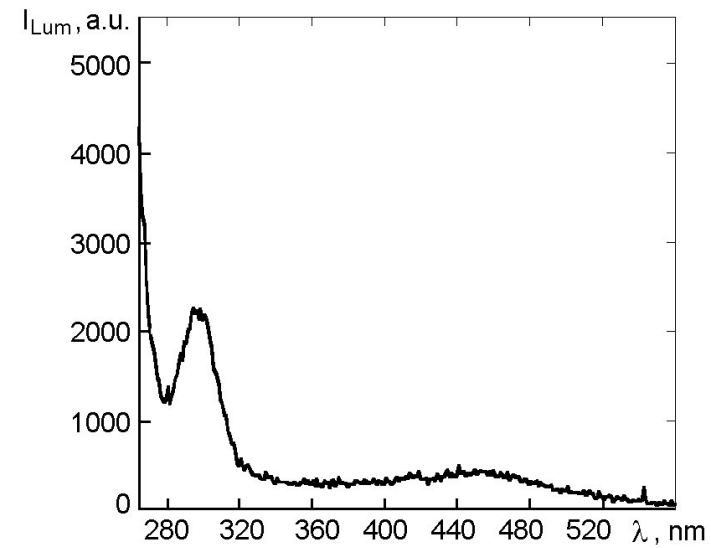

Fig. 4. The photoluminescence spectrum at $77 \mathrm{~K}$, excitation in $243 \mathrm{~nm}$.

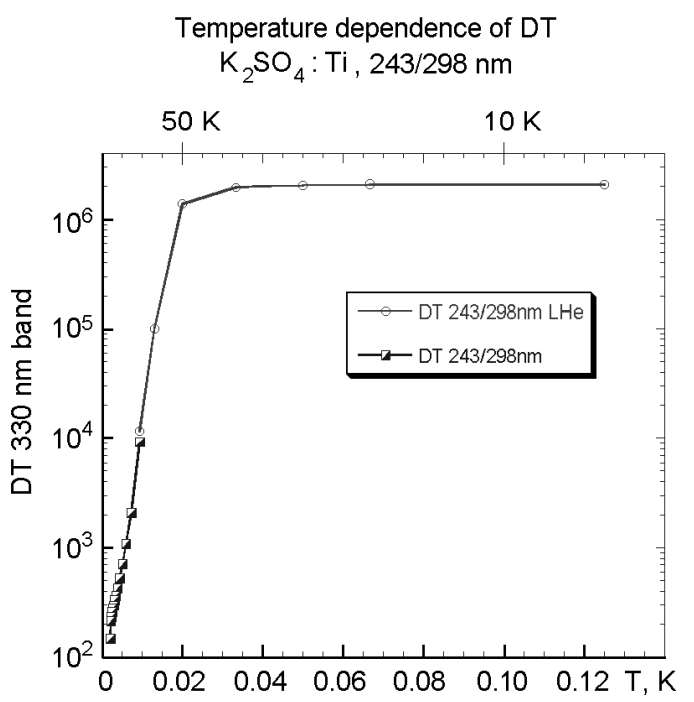

Fig. 5. Temperature dependence of the decay time values of the $296 \mathrm{~nm}$ band, excitation in $243 \mathrm{~nm}$.

The temperature dependence of the decay time of the emission band at $330 \mathrm{~nm}$ is given in Fig. 2. In Fig. 3 and 4 the excitation and emission spectra are shown, respectively, demonstration of one more emission center is proved in a matrix of potassium sulphate with an emission about $296 \mathrm{~nm}$ and excitation near to $243 \mathrm{~nm}$ peaks.

Value of a radiative lifetime of the $296 \mathrm{~nm}$ band several times exceeds those of the other two bands described above. Furthermore, the temperature dependence of the decay time of the emission is different: the plateau extends to higher temperatures, and then drops sharply (Fig. 5). 
Detailed measurements of temperature dependences of the decay times and carefully distinquished luminescence spectra clearly proved three emission centers associated with monovalent thallium. Two of them arise due to two positions of potassium ions in the structure of potassium sulphate, the third can be associated with the $\mathrm{TI}^{+}$with a defect nearby.

\section{References}

1. A.N.Gruzintsev, G.A.Emel'chenko, Yu.V.Yermolayeva et al., Materials for Nanophotonics: the Formation and Properties of Nanoparticles and Nanostructures, ISMA, Kharkiv (2010) [in Russian].

2. M.I.Samoilovitch, S.M.Klesheva, A.F.Beljanin et al., Microsyst. Techn., 6, 3 (2004); 7, 2 (2004); 8, 9 (2004).

3. B.Andriyevsky et al., J.Phys.Chem. Solids, 70, 1109 (2009).

4. J.A.McGinnety, Acta Crystallogr., B28, 2845 (1972).

5. H.Arnold, W.Kurtz, A.Richter-Zinnius et al., Acta Crystallogr., B37, 1643 (1981).

6. K.S.Aleksandrov, B.V.Beznosikov, Ferroelectrics, 117, 331 (1991).
7. S.D.Russell, R.Merlin, Phys.Rev., B33, 1871 (1986).

8. S.A.Ahmed, Phys. Stat. Solidi B, 195, 113 (1996).

9. K.Ojima, Y.Nishihata, A.Sawada, Acta Cryst., B51, 287 (1995).

10. S.Bin Anooz, R.Bertram, D.Klimm, http://arxiv.org/abs/0801.2077v1.

11. B.-K.Choi, Y.-H.Cho, H.-K.Lee, J.Phys.Chem. Solids, 54, 197 (1993).

12. J.E.Diosa, R.A.Vargas, I. Albinsson et al., Solid State Commun., 136, 601 (2005).

13. M.Miyake, S.-I.Iwai, Phys.Chem.Minerals, 7, 211 (1981).

14. V.S.Osminin, V.G.Plekhanov, N.I.Silkin, $Z h$. Prikl. Spektr., 21, 88 (1974).

15. N.E.Lushchikand, I.A.Meriloo, Izv.Akad. Nauk SSSR, Ser.Fiz., 30, 1517 (1966).

16. R.L.Garifullina, V.F.Krutikov, N.I.Silkin et al., Fiz. Tverd.Tela, 14, 618 (1972).

17. V.S.Kumar, B.S.Acharyulu, S.B.Sastry, Radiat. Eff. and Defects in Solids, 127, 215 (1993).

18. M.V.Eremin, N.I.Silkin, Phys.Stat. sol.(b), 84, 803 (1977).

19. M.K.Myrzakhmet, M.Nikl, V.Jary, Vestnik ENU: Ser. Tst.-Tekhn., 4, 81 (2010). 